\title{
FOUNDATION MATHEMATICS FOR ENGINEERS
}


FOUNDATION

MATHEMATICS

FOR ENGINEERS

John Berry and Patrick Wainwright

palgrave macmillan 
(C) John Berry and Patrick Wainwright 1991

All rights reserved. No reproduction, copy or transmission of this publication may be made without written permission.

No paragraph of this publication may be reproduced, copied or transmitted save with written permission or in accordance with the provisions of the Copyright, Designs and Patents Act 1988 or under the terms of any licence permitting limited copying issued by the Copyright Licensing Agency,

33-4 Alfred Place, London WC1E 7DP.

Any person who does any unauthorised act in relation to this publication may be liable to criminal prosecution and civil claims for damages.

First edition 1991

Published by

MACMILLAN EDUCATION LTD

Houndmills, Basingstoke, Hampshire RG21 2XS

and London

Companies and representatives

throughout the world

ISBN 978-0-333-52717-7

ISBN 978-1-349-11717-8 (eBook)

DOI 10.1007/978-1-349-11717-8

A catalogue record for this book is available from the British Library

Logging, pulping and manufacturing processes are expected to conform to the environmental regulations of the country of origin. 


\section{CONTENTS}

Preface

Chapter 1 Proportionality and Linear Laws

vii

Chapter 2 Quadratics and Polynomials

Chapter 3 Logarithms and Exponential

66

Functions

Chapter 4 Trigonometric Functions

Chapter 5 Trigonometry

Chapter 6 Further Algebraic Skills

169

Chapter 7 Differentiation

228

Chapter 8 Integration

296

Chapter 9 Differential Equations

367

Chapter 10 Numerical Analysis

392

Chapter 11 Vectors

409

Chapter 12 Matrices

430

Chapter 13 Mathematical Modelling

473

Appendix 1 Units

483

Appendix 2 Mathematical Formulas

484

Answers to Exercises

492

Index 


\section{PREFACE}

Mathematics is an essential tool for the engineer and applied scientist and mathematics is often up to one third of an engineering students' curriculum in the first year. To succeed in their studies in Higher Education, it is important for students to have a solid foundation of mathematics and science on which to build. In the past, the standard route into engineering was for students with GCE Advanced levels in mathematics and science or their BTEC equivalent. Now there is a chance for men and women, school leavers and older people without the necessary formal qualifications to move into engineering by joining one of the Foundation Engineering courses which are now part of many engineering degree courses. This book is the result of several years' experience teaching mathematics to engineering students at this Foundation level.

The mathematics syllabus for these Foundation courses is essentially a sound conceptual understanding of algebra, trigonometry, functions and calculus together with the confidence to apply the skills in engineering applications. With the arrival in the classroom of powerful computer algebra packages, such as DERIVE, the need for many hours' practice at standard exercise is now less important, and teachers of engineering mathematics can concentrate on a sound understanding of the concepts and applications of the theory. If the student has access to graphical packages and/or computer algebra packages then we would recommend that these packages are used in conjunction with the theory and problem solving activities in this book.

This book is intended to cover the mathematical content of Foundation Engineering courses (such as HITECC) in Higher Education. Each chapter contains applications of the mathematical theory so that students can see the relevance and need for the mathematics as well as have the opportunity to use their new mathematical skills. The applications are mainly drawn from science because at the Foundation level students will have little engineering background to use. In writing this book we have not made any distinction between the various areas of engineering since we consider that, no matter what discipline the student may go into, they all have the same common mathematical core syllabus.

Although primarily written for engineering students, the text should also be of value to science students whose mathematical requirements are similar to those of the engineer. For example, this 
book would be suitable for some of the new AS level courses which include calculus.

Each chapter identifies specific learning objectives for the student and these objectives are tested at the end of the chapter. The final chapter introduces the important topic of mathematical modelling. It is natural in a book containing applications to identify the problem solving skills needed for the prospective engineering student. Many courses now contain mathematical modelling as a part of the curriculum so that this chapter should provide a framework for these modules.

We would like to thank Sharon Ward for the expert typing of the manuscript and for her patience in the many corrections and amendments needed. We would also like to thank our colleagues within our Polytechnics for their advice during the preparation of this book and for the staff at Macmillans and their reviewers for their helpful suggestions, many of which have been incorporated into the text. We also thank the Controller of Her Majesty's Stationery Office for permission to use the 'shortest stopping distances' extract from the Highway Code, and Guinness Publishing for permission to reproduce one fact from the The Guinness Book of Records 1984 (copyright (C) Guinness Publishing Ltd 1983).

Patrick Wainwright John Berry 